\title{
Jaritz, Gerhard and Katalin Szende, eds. 2016. Medieval East Central Europe in a Comparative Perspective. From Frontier Zones to Lands in Focus. Abingdon, UK: Routledge. 265 pp., illus.
}

\author{
Reviewed by Ottó Gecser, Eötvös Loránd University, Budapest
}

Based on its availability also in paperback and as an e-book, this comprehensive volume edited by two professors of Medieval Studies from the Central European University in Budapest is apparently destined by the publisher for a wider scholarly readership. It consists of fourteen articles plus an introduction by Gerhard Jaritz and an afterword by János M. Bak. The fourteen articles are grouped in five sections- "What is East Central Europe?", "Political practices," "Religious space," "Urban space," as well as "Art and literature" - and their authors belong by origin or place of residence to, at least, ten modern states, some of which cannot by any means be regarded as East Central European. In what follows, I will focus on the way East Central Europe (ECE) is conceived of in the book, and mention explicitly only those chapters that seem to mark sufficiently different conceptions of how to define it.

In the first article (9-23), Nora Berend approaches the meaning of ECE, and of historical regions more generally, with a refreshing nominalism, arguing against the projection of modern political ideologies back in the Middle Ages in order to create something genuinely different on the supranational level (in addition to the national one). Medieval authors never regarded themselves or others as East Central European, even if sometimes they did talk about regions of their own making in a sense comparable to that of ECE (i.e. geographical units above the territories of specific rulers). Nor is it the case that medieval ECE or any other region of medieval Europe was consistently separate on a range of different criteria (economic, social, or cultural) from other regions of the continent. As Berend explains, different types of comparison fit in with different large-scale categorizations of geographical space, even if some categorizations are more versatile than others.

A modern political context of studying ECE in the Middle Ages is discussed by Anna Kuznetsova's article (37-44) on the region in Russian historiography. In the Soviet era ECE was part of the broader field of the history of "peoples' democracies" and institutionally, even in the case of Hungary and Romania, it was, and still is, connected primarily to centers of Slavic Studies. There was, understandably, little interest in grasping regional specificities before the 1990s, especially not in the manner of Oskar Halecki or Jenö Szücs, the initiators of the concept of ECE as a historical region in its own right, who emphasized its fundamental difference from Russia since the Middle Ages; but, in spite of the revival of comparative studies in the post-

*gecsero@tatk.elte.hu

$($ (c) $)$ EY

ULIS D-Sente 
Gecser, Ottó. "Jaritz, Gerhard and Katalin Szende, eds. 2016. Medieval East Central Europe in a Comparative Perspective. From Frontier Zones to Lands in Focus. Abingdon, UK: Routledge. 265 pp., illus." Hungarian Cultural Studies. e-Journal of the American Hungarian Educators Association, Volume 11 (2018) DOI: 10.5195/ahea.2018.335

Soviet period, many Russian historians have seen ECE—called Central, not East Central—as a political construct, for the most part.

The question of what kind of region ECE was in the Middle Ages is answered by the authors of the volume (implicitly or explicitly) along three main, but not exclusive, lines: it was an inter-imperial zone, a frontier of Latin Christendom, or a periphery of the (or a) center in the West. Stefan Burkhardt, who introduces the term "inter-imperial zone," compares Hungary with two further regions of this kind: the papal state on the one hand, and Venice plus Southern Italy on the other (47-61). His point is that all three had to negotiate their status with the Holy Roman Empire and the Byzantine Empire in the first place, but they could also improve their position through switching their allegiance rather freely between the two sides since neither of the two wanted to conquer the inter-imperial zones. One major implication of Burkhardt's analysis is that "betweenness", a characteristic frequently regarded as typical of ECE (what in Hungary the poet Endre Ady famously described as Komp-ország, "Ferry-land," that belongs neither to the West, nor to the East and swings constantly between the two), is not sufficiently specific to the region (or it was not so in the Middle Ages).

Márta Font (24-36) discusses medieval ECE as an inter-imperial zone in a different way. Her question is how ECE came to be differentiated from Eastern Europe (EE) between the tenth and the twelfth centuries. Initially, the future ECE and EE were part of the same region, "Middle Europe," flanked by the two great empires and characterized by a mixture of influences coming from East and West. In Font's view, the main factors which lead to a separation of ECE and EE are the stability of dynastic power (based on legitimacy, well-regulated succession, inclusion in large-scale aristocratic marital networks etc.) and the chances of Byzantium and the Holy Roman Empire to shape the fate of Middle Europe whether intentionally or unintentionally (through, for example, settlers coming from their territories). Those parts of Middle Europe where more stable dynastic states mostly under western influence could emerge came to constitute ECE.

Johnny Grandjean Gøgsig Jakobsen approaches ECE as a frontier of Latin Christendom in his comparison of the Dominican provinces of Bohemia, Dacia (i.e. Scandinavia), Hungaria, Polonia, and Saxonia (123-136). What makes these provinces similar to each other and different from the core provinces of the order away from the frontiers is their more continuous and more systematic contacts with pagans, new converts, or non-Catholic Christians. Their position on the frontier had an effect on the daily activities of the friars belonging to them (preaching local crusades, missionizing, acting as parish priests etc.) and made them stronger vis-à-vis the secular clergy - and, thus, more efficient transmitters of papal will - than their confreres were in the core provinces.

If we turn to a closely related topic, the demographics of mendicant friars (Augustinian Hermits, Carmelites, Dominicans, Franciscans etc.) more generally, studied by Beatrix F. Romhányi (99-122), the belt of frontier provinces from Scandinavia to Hungary loses its coherence. In terms of the ratio of the mendicant population to the overall population in a given region, for instance, Hungary is much closer to the British Isles or Denmark than to Bohemia or Poland, and even the last two areas are quite different, with Poland being on par with France or Germany, and Bohemia being far below them. Since this ratio also indicates the capability and willingness of the wider population to build convents and support the friars there, the 
aforementioned differences (and a range of others analyzed by Romhányi) may have a significance far beyond the fortunes of religious orders.

Center-periphery relations lend themselves as a useful, if frequently oversimplified, arrangement for tracing the spatial diffusion of cultural innovations or models. That novelties of Europe-wide diffusion tend to come from outside ECE does not seem to be questioned by the authors in the book, but they emphasize the intricacies of transmission and the local processes of adaptation and transformation. One major example of the geographical spread of cultural models in the Middle Ages is the princely foundation or restructuration of towns. Olha KozubskaAndrusiv (139-156) shows how agglomeration type, loosely structured urban centers with a fortified core and several satellite settlements in Galicia-Volhynia, a principality of the Kievan Rus' (in modern-day Western Ukraine) came to be transformed, from the second half of the thirteenth century, into spatially unified autonomous towns with a privileged stratum of burghers living under Magdeburg law.

Similar processes of urban development to that of Galicia-Volhynia unfolded in other areas of ECE as well, and a frequently present feature of them was the grid plan underlying the (re)organization of urban space. Discontinuous with its antecedents in Antiquity, the grid plan was preferred by rulers in ECE, argues Katalin Szende (157-184), for its making easier and smoother the allotment of plots and houses to a relatively large number of would-be-burghers, the possession of which was a precondition of their privileged status under Magdeburg law. Szende also shows that ECE was not homogenous on this criterion, because even though the grid plan was widespread from Plzen to Lviv and from Zagreb to Wrocław, it was curiously absent in Hungary, possibly because Hungarian rulers were less directly involved in supervising the recruitment of settlers than their counterparts elsewhere in the region. Models of (re)organizing urban centers either spatially or legally reached ECE as flows of settlers from more urbanized Western regions brought along their skills and practices. This "colonial" aspect of urbanization makes ECE similar to early Spanish America, where the grid plan was also essential for the creation of new towns. Szende uses this comparison to underline the advantages of the grid plan for sovereigns intending to settle and govern (relatively) large masses of newcomers in an efficient manner by distributing plots (the bases of housing, economic activities, and taxation) in standard sizes, systematically and transparently.

A particularly complex interaction between center(s) and peripheries emerges from József Laszlovszky's article (81-98) on why Hungarian kings chose to bury their family members or to be buried themselves in Cistercian monasteries in the thirteenth century. On the one hand, the Cistercian order was very much centered on North-Western Europe whether in terms of chronology, organization, or spatial distribution. It was their first monastery in Cîteaux, in Burgundy, which initiated and supervised the order's expansion through the foundation of daughter houses, and hosted the yearly general chapters with compulsory attendance for all Cistercian abbots. On the other hand, through supporting the foundation of Cistercian houses which could, in turn, found and control (through yearly visitations) their own daughter houses, local rulers could create smaller centers within the Europe-wide network that suited their plans and interests. Initially, the order was reluctant to allow the burial of secular persons in its monasteries and the revision of this policy was rather piecemeal. But initiatives to this effect came not merely from the core area but also from other peripheries bypassing the core. The 
series of Hungarian royal burials in Cistercian abbeys started with the first wife of King Andrew II (r. 1205-1235), Gertrude of Andechs-Meran (d. 1213), who was reburied in the monastery of Pilis after a first resting place in Leles in modern-day Slovakia. Laszlovszky shows how this decision (and a number of subsequent ones also favoring the Cistercians) could rely on models in the dynastic network of the Árpádians and the monastic network of the Cistercians involving places as distant from each other as Heligienkreuz in Austria or Las Huelgas in Spain.

On the whole, it is precisely the emphasis on networks, on multidirectional and multilevel connections in this book that makes it different from traditional studies of medieval ECE interested, above all, in its uniqueness and essential features. If, however, the readers ask themselves whether it is profitable indeed, in terms of pure scholarship, to choose medieval ECE as the focus of historical research, then the answer the book seems to give is not straightforward. On the one hand, to understand an area (historically or otherwise) one has to compare it to other areas, and a rather vague supranational region is a better point of departure than modern national territories. On the other hand, if the manifold similarities and differences (or the connections and the lack of thereof) between ECE and other European (or non-European) regions continue to be studied in the directions explored in this volume, then the emerging spatial patterns may suggest better classifications than those ECE can be meaningfully part of. 